\title{
Trends in Area, Production, Productivity and Trade of Chick Pea in India
}

\author{
Samriti", Subhash Sharma, Ravinder Sharma and Ankit Pathania
}

Department of Social Sciences, Dr YS Parmar University of Horticulture and Forestry, Nauni, Solan, Himachal Pradesh, India

*Corresponding author: jsamriti1994@gmail.com (ORCID ID: 0000-0002-5217-6599)

Received: $19-12-2019$

Revised: $23-03-2020$

Accepted: 26-05-2020

\begin{abstract}
Chick pea is an important pulse crop and steady source of human nutrition, as it is an important component of production systems that are resilient to climate change. Asia and Africa contribute around 80 per cent of world production. India is a leader of production and consumption of chick pea as growing it is cost effective option for developing countries but yield of chick pea is comparatively low due to poor spread of improved varieties and technologies. In this study, growth trend of area, production and productivity of chick pea was estimated. The contribution of area and productivity in the production growth were also estimated and it was found that the contribution of area in production was high. Demand and supply gap of chick pea has been increased, so India has become the major importer of chick pea. Thus, to enhance domestic chick pea production and productivity generation and dissemination of technologies is a matter of great challenge and favorable policy measures are to requisite.
\end{abstract}

\section{Highlights}

( India is leading in production and consumption of chick pea but productivity is comparatively low due to poor spread of improved varieties and technologies.

Keywords: Chick pea, production, trend, import, export

Pulses historically have been one of the most important constituent of the Indian cropping and consumption patterns and long considered "the poor man's meat" as it is one of the less expensive sources of protein (Mohanty and Satyasai 2015). Among pulses, chick pea (Cicer arietinum) is preferred to food legumes because of its multiple uses for growing population across the world. During 2017-18, globally it was grown on 149.66 lakh ha area, with the total production of 162.25 lakh tonnes (FAOSTAT, 2019) and average productivity of $1252 \mathrm{~kg} / \mathrm{ha}$. Out of which, 71 per cent of global area with 70 per cent of global production of chick pea is contributed by India as it ranks $1^{\text {st }}$ in area and production but lags behind several countries in terms of productivity because of poor adoption of improved varieties and production technologies by farmers'. Apart from India, Australia (12.35\%),
Myanmar (3.25\%) and Ethiopia (2.92\%) are the major chick pea producing countries of the world. The chick pea production in India has gone up from 38.55 to 112.29 lakh tonnes during 2000-01 to 2017-18, while the area has also gone up from 51.85 to 105.61 lakh ha, whereas, the yield has steadily increased from $744 \mathrm{~kg} / \mathrm{ha}$ to $1063 \mathrm{~kg} / \mathrm{ha}$ during the same period (Table 2). Madhya Pradesh is leading state in terms of area and production as it contributes around 34 and 40 per cent share to the total area and production of gram in the country (Annual Report 2017-18, Directorate of Pulses Development). Due to stagnant productivity over the years, chick pea import to India has been bagged in largely to

How to cite this article: Samriti, Sharma, S., Sharma, R. and Pathania, A. (2020). Trends in area, production, productivity and trade of chick pea in India. Economic Affairs, 65(2): 261-265.

Source of Support: None; Conflict of Interest: None 
counterbalance domestic short supply and hence it became the major importer of chick pea (5.90 lakh tonnes) during 2017-18. The countries which exports chick pea to India are Canada, Australia, Iran, Myanmar, Tanzania, Pakistan, Turkey and France. In spite of this, India is also a major exporter ranking third i.e. 2.12 lakh tonnes (FAO2019) and its export destinations are USA, UK, Saudi Arabia, UAE, Sri Lanka, and Malaysia. Therefore, this study examines the chick pea production, value and trade on a global and country basis to determine trends in area, production and yield.

\section{METHODOLOGY}

Theoretical foundation of the study about global scenario of chick pea is based on the secondary data available at the Food and Agriculture Organization (FAO) Corporate Statistical Database (FAOSTAT) for the period of 2017-18. Detailed area, production and yield data of chick pea were available in "Agriculture statistics at a glance" for India. When the analysis was carried out for this study, the time series data on area, production and yield of chick pea were taken from 2000-01 to 2017-18. Statistical measures such as the average, percentage and the compound growth rates have been computed to analyze the trends. Compound growth rates of area, production and yield of chick pea for India as a whole were estimated for the period (2000-01 to 2017-18) by fitting an exponential function of the following form $\mathrm{Y}=\mathrm{Ab^{t }}$ . It was converted into log linear function with the help of logarithmic transformation as under:

$$
\log Y=\log A+b t
$$

Where, $Y=$ Dependent variable Area/Production/ Yield

$$
\begin{aligned}
& A=\text { Constant } \\
& t=\text { Independent variable (time in a year) }
\end{aligned}
$$

Compound growth rate was calculated by using the formula:

$$
C G R=b^{*} 100
$$

For significant testing $\mathrm{t}$ value was calculated using formula:

$$
t=\frac{C G R}{S E(C G R)}
$$

\section{Decomposition of Analysis}

To estimate the contribution of area, productivity and interaction of the two in total production of chick pea, the following additive scheme of decomposition can be used:

$$
1-\left[\frac{Y_{o} \Delta A}{P}\right]+\left[\frac{A_{o} \Delta Y}{P}\right]+\left[\frac{\Delta A \Delta Y}{P}\right]
$$

Where,

$$
\begin{aligned}
& P=\text { Change in production } \\
& A_{O}=\text { Area in base year } \\
& A n=\text { Area in current year } \\
& Y_{O}=\text { Yield in base year } \\
& Y n=\text { Yield in current year } \\
& \Delta A=\text { Change in area }\left(A n-A_{O}\right) \\
& \Delta Y=\text { Change in yield }\left(Y_{n}-Y_{O}\right) .
\end{aligned}
$$

\section{RESULTS AND DISCUSSION}

\section{Global Scenario of Chick Pea}

Chick pea is an important pulses crop and grown all over the world. About 71 per cent of global area with 70 per cent of global production of chick pea is contributed by India. There are mainly two types chick pea produced i.e. Desi and Kabuli. The Desi type chick peas contribute to around 80 per cent and the Kabuli type around 20 per cent of the total chick pea production. The major producing countries of Desi chick pea are India, Pakistan, Myanmar, Australia and Bangladesh. Countries like Turkey, Iran, Ethiopia, Mexico, Syria, Spain, Canada, United States, Algeria, Ethiopia, Malawi, Sudan, Tanzania, Tunisia, Spain and Portugal are the major producers of Kabuli chick pea. In case of productivity Ethiopia is leading country (2038 kg/ha) followed by Mexico (1918 kg/ha) and Australia (1875 kg/ha).

It just contributes 2.92 per cent and 1.55 per cent in production and area of the world but productivity is very high as compared to India. Productivity of India was found to be $1063 \mathrm{~kg} / \mathrm{ha}$. So, in productivity India ranks $6^{\text {th }}$ in the world this is a point of concern (Table 1). It can be suggested from the data that more focus should be given on the improvement of the chick pea varieties. 
Table 1: World area, production and productivity of chick pea in 2017-18

\begin{tabular}{|c|c|c|c|c|c|}
\hline Country & Area (Lakh ha) & $\%$ Contribution & Production (Lakh tonnes) & $\%$ Contribution & Yield (kg/ha) \\
\hline India & 105.61 & 70.57 & 112.29 & 69.21 & 1063 \\
\hline Australia & 10.69 & 7.14 & 20.04 & 12.35 & 1875 \\
\hline Pakistan & 9.71 & 6.49 & 3.3 & 2.03 & 340 \\
\hline Iran & 5.66 & 3.78 & 2.71 & 1.67 & 480 \\
\hline Russian Federation & 4.57 & 3.05 & 4.18 & 2.58 & 916 \\
\hline Turkey & 3.92 & 2.62 & 4.7 & 2.90 & 1197 \\
\hline Myanmar & 3.76 & 2.51 & 5.27 & 3.25 & 1402 \\
\hline USA & 2.43 & 1.62 & 3.13 & 1.93 & 1291 \\
\hline Ethiopia & 2.32 & 1.55 & 4.74 & 2.92 & 2038 \\
\hline Mexico & 0.99 & 0.66 & 1.89 & 1.16 & 1918 \\
\hline World & 149.66 & & 162.25 & & 1252 \\
\hline
\end{tabular}

Source: Food and Agriculture Organization (2019).

\section{Indian Scenario of Chick Pea}

\section{Growth trends of chick pea}

In India, chick pea producing states are Madhya Pradesh, Uttar Pradesh, Rajasthan, Maharashtra and Andhra Pradesh. Madhya Pradesh has major share i.e. around 40 per cent in the India's chick pea production. The level of growth in output is jointly determined by the growth rate in area and that in yield. The purpose is to examine the performance of chick pea in the country and see if there have been noticeable changes during the years 2000-01 to 201718. Compound growth rates of area, production and productivity of chick pea were worked out to 3.1, 4.7 and 1.5 per cent respectively during 2000-01 to 201718 and it is found that there is significant increase in area, production and productivity of chick pea in India (Table 2). Keeping in view, the per capita availability of chick pea, there is an urgent need to increase the production through crop specific and region specific strategies. This bleak performance of expansion of area under chick pea and consequent slow growth of production is cause of concern, as India is the largest producing, consuming and importing country.

Table 2: Compound growth rate in area, production and productivity of chick pea in India

\begin{tabular}{llll}
\hline Years & $\begin{array}{l}\text { Area } \\
\text { (Lakh ha) }\end{array}$ & $\begin{array}{l}\text { Production } \\
\text { (Lakh } \\
\text { tonnes) }\end{array}$ & $\begin{array}{l}\text { Yield } \\
\text { (kg/ha) }\end{array}$ \\
\hline $2000-01$ & 51.85 & 38.55 & 744.00 \\
$2001-02$ & 64.16 & 54.73 & 853.00 \\
$2002-03$ & 59.06 & 42.37 & 717.00 \\
$2003-04$ & 70.48 & 57.18 & 811.00
\end{tabular}

\begin{tabular}{llll}
$2004-05$ & 67.15 & 54.69 & 815.00 \\
$2005-06$ & 69.26 & 56.00 & 808.00 \\
$2006-07$ & 74.94 & 63.34 & 845.00 \\
$2007-08$ & 75.44 & 57.49 & 762.00 \\
$2008-09$ & 78.93 & 70.60 & 895.00 \\
$2009-10$ & 81.69 & 74.76 & 915.00 \\
$2010-11$ & 91.86 & 82.21 & 895.00 \\
$2011-12$ & 82.99 & 77.02 & 928.00 \\
$2012-13$ & 85.22 & 88.32 & 1036.00 \\
$2013-14$ & 99.27 & 95.26 & 960.00 \\
$2014-15$ & 82.51 & 73.32 & 889.00 \\
$2015-16$ & 83.99 & 70.58 & 840.00 \\
$2016-17$ & 95.39 & 90.75 & 951.00 \\
$2017-18$ & 105.61 & 112.29 & 1063.00 \\
\hline Coefficient (b) & $0.031(0.003)$ & $0.047(0.006)$ & $0.015(0.003)$ \\
\hline CGR (\%) & $3.1^{* *}$ & $4.7^{* *}$ & $1.5^{* *}$ \\
\hline
\end{tabular}

** Significant at 5 per cent level of significance.

Figures in parentheses are standard error.

\section{Decomposition analysis}

The analysis of the factors affecting the total production of the chick pea (Table 3) indicates that the effect of area is maximum in chick pea (54.24 per cent). The contribution of Productivity is 22.43 per cent. Chick pea shows positive interaction effect (23.26 per cent).

Table 3: Area effect, yield effect and interaction effect on production growth of chick pea

\begin{tabular}{cll}
\hline Sr. No. & Description (\%) & Chick pea \\
\hline 1 & Change in area variance & 54.24 \\
2 & Change in yield variance & 22.43 \\
3 & $\begin{array}{l}\text { Interaction between changes in mean } \\
\text { area and mean yield }\end{array}$ & 23.26 \\
\hline
\end{tabular}




\section{Export Import Intelligence of Chick Pea}

Australia is the major exporter of chick pea in the world. It nearly meets half of the world export demand. The chick pea export of the country was 9.26 lakh tonnes to the market followed by Russia (2.43 lakh tonnes) as shown in table 4. India while being the major producer and importer of chick pea is also a major exporter ranking third (2.12 lakh tonnes), after Russian federation (FAO2019). Mexico rank fourth with the commodity being exported to over 50 countries worldwide.

Table 4: Major chick pea exporting countries from 2010 to 2018

\begin{tabular}{cll}
\hline S1. No. & Country & Export (lakh tonnes) \\
\hline 1 & Australia & 9.26 \\
2 & Russian Federation & 2.43 \\
3 & India & 2.12 \\
4 & Mexico & 1.49 \\
5 & Canada & 0.81 \\
6 & Argentina & 0.77 \\
7 & USA & 0.70 \\
8 & Ethiopia & 0.59 \\
9 & Turkey & 0.21 \\
\hline
\end{tabular}

Source: $F A O, 2019$.

The table 5 revealed that India is the major importer of chick pea due to its large population size. India imports 5.90 lakh tonnes chick pea followed by Bangladesh (2.08 lakh tonnes) and Algeria (0.72 lakh tonnes). It is found that India's quantity of import exceeds the quantity of export and it reflects the negative balance of trade in case of chick pea.

Table 5: Major chick pea importing countries from 2010 to 2018

\begin{tabular}{cll}
\hline S1. No. & Country & Import (lakh tonnes) \\
\hline 1 & India & 5.90 \\
2 & Bangladesh & 2.08 \\
3 & Algeria & 0.72 \\
4 & Sri Lanka & 0.27 \\
5 & Egypt & 0.25 \\
6 & Iran & 0.18 \\
7 & Iraq & 0.08 \\
8 & France & 0.05 \\
9 & Greece & 0.04 \\
\hline
\end{tabular}

Source: $F A O, 2019$.

\section{Trade Destination of Chick Pea}

Chick pea have entered world trade as consuming countries have been unable to meet demand through their domestic production. India, while being the largest producer and importer of chick pea is also a major exporter. Major export destinations of India for Chick pea were Pakistan (21.60\%) followed by Algeria (11.6\%) and U Arab EMTS $(10.60 \%)$. India imports maximum share of chick pea from Australia (85.10\%) followed by Russia $(4.7 \%)$ and Tanzania (3.8\%) as shown in table 6. India also exports chick pea to different countries namely USA, UK, Saudi Arabia, UAE and Sri Lanka. The major trading centers of Chick pea in India are Indore (Madhya Pradesh), Bhopal (Madhya Pradesh), Vidisha (Madhya Pradesh), Jalgaon (Maharashtra), Latur (Maharashtra), Mumbai (Maharashtra), Akola (Maharashtra), Jaipur (Rajasthan), Bikaner (Rajasthan), Kota (Rajasthan), Jodhpur (Rajasthan), Sriganaganagar (Rajasthan), Hanumangarh (Rajasthan), Delhi, Chennai, Kanpur, Hapur, Hyderabad, Vijayawada, Gulbarga, Sirsa, Jalandhar, Ludhiana and Sangrur.

Table 6: India's trade destinations of chick pea in 201718

\begin{tabular}{cll}
\hline S1. No. & Export Destinations & Import Sources \\
\hline 1 & Pakistan $(21.60 \%)$, & Australia $(85.1 \%)$, \\
2 & Algeria $(11.60 \%)$ & Russia $(4.7 \%)$ \\
3 & U Arab EMTS (10.60\%) & Tanzania $(3.8 \%)$ \\
4 & Saudi Arab $(9.50 \%)$ & USA $(1.4 \%)$ \\
5 & Sri Lanka $(7.30 \%)$ & Canada $(0.91 \%)$ \\
\hline
\end{tabular}

Figures in parenthesis indicates percentage share of global import/ export

Sources: Ministry of Commerce and Industry. GOI.

\section{CONCLUSIONS}

Chick pea is an important source of income and nutrition to number of smallholder farmers and consumers around the world. The main objective of this study was to examine the global and regional trends in area, production, yield and trade of chick pea. Present study revealed that, India ranks first in terms of area and production but lags behind several countries in terms of productivity of chick pea. Low yield in India compared to other chick pea growing countries is attributed to poor spread of improved varieties and technologies, abrupt climatic changes, vulnerability to pests and diseases, 
and generally declining growth rate of total factor productivity. Production is the combined effect of area and productivity, growth of production is majorly contributed by areas. Due to stagnant production and productivity over the years, chick pea import to India have been brought in largely to counterbalance domestic short supply of pulse as compared to emerging demand.

\section{REFERENCES}

Agricultural Statistics at a Glance. 2017. Directorate of Economics and Statistics, Department of Agriculture, Cooperation and Farmers' Welfare, Ministry of Agriculture, Government of India, New Delhi.

Annual Report. 2017-18. Directorates of Pulses Development, Bhopal. Government of India.

Department of Commerce. 2018. Ministry of Commerce and Industry. Government of India, New Delhi.

Food and Agriculture Organization. 2019. FAOSTAT Statistical Database of the United Nation Food and Agriculture Organization Statistical Division. Rome.

Jukanti, A.K., Gaur, P.M., Gowda, C.L. and Chibbar, R.N. 2012. Nutritional quality and health benefits of chick pea (Cicer arietinum L.): A Review. British Journal of Nutrition, 108: S12-S26.
Kumar, S., Singh, R., Sharma, V., Choubey, A.K. and Shah, S. 2014. Yield gap and economics of chick pea (Cicer arietinum L.) cultivation in low hills of Himachal Pradesh. Journal of Agricultural Research, 40: 45-49.

Inbasekar, K. 2014. Pulse Production in India: Challenges and Strategies. Economic Affairs, 59: 403-414.

Malunga, L.N., Bar-El, S.D., Zinal, E., Berkovich, Z., Abbo, S. and Reifen, R. 2014. The potential use of chick peas in development of infant follow-on formula. Nutrition Journal, 13: 8.

Maurya, O.P. and Kumar, H. 2018. Growth of Chick pea Production in India. Journal of Pharmacognosy and Phytochemistry, 7: 1175-1177.

Merga, B. and Haji, J. 2019. Economic importance of chick pea: Production, value, and world trade. Cogent Food and Agriculture, 5: 1-12.

Mohanty, S. and Satyasai, K.J. 2015. Feeling the Pulse, Indian Pulses Sector. NABARD Rural Pulse, 10: 1-4.

Tiwari, A.K. and Shivhare, A.K. 2017. Pulses in India: Retrospect and Prospects, Govt. of India, Ministry of Agri. \& Farmers Welfare (DAC\&FW), Directorate of Pulses Development, Vindhyachal Bhawan, Bhopal, M.P. 
